\title{
Rotigotine-induced nail dyschromia in a patient with Parkinson disease
}

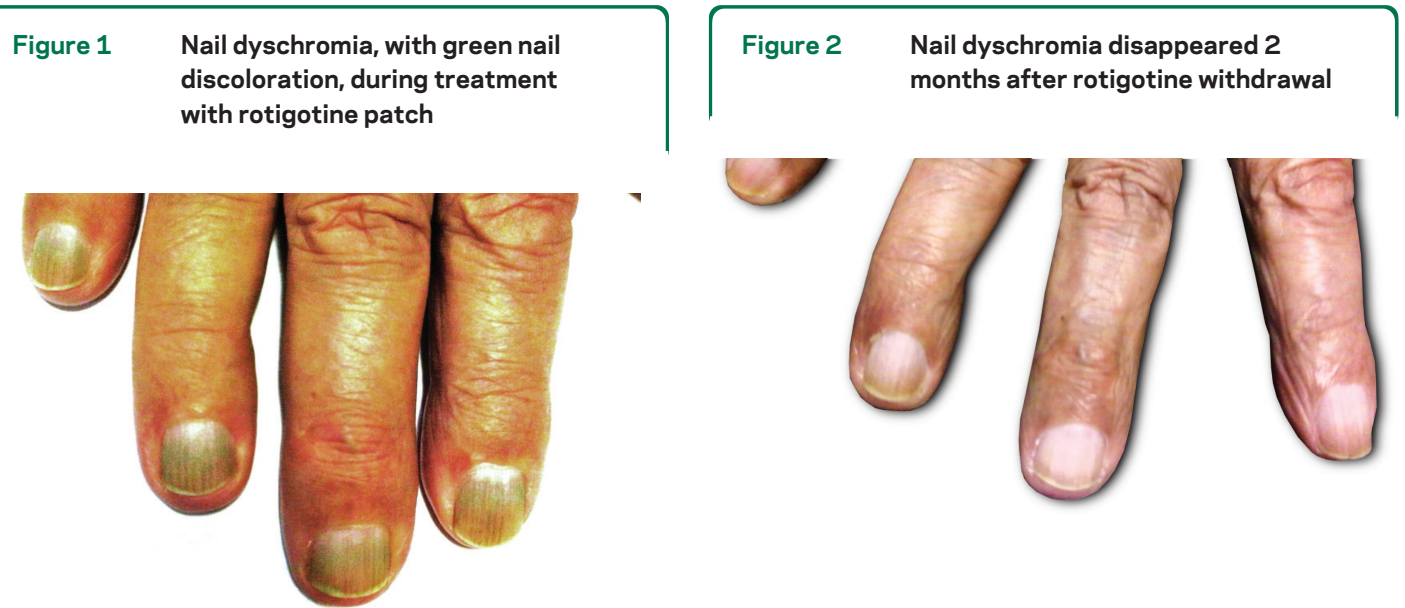

An 80-year-old man with a 15-year history of Parkinson disease, experiencing complications of levodopa therapy (wearing-off phenomenon and peak-dose dyskinesias), was initiated on rotigotine patch $(2 \mathrm{mg}$, titrated up to $6 \mathrm{mg} /$ day). While this drug brought significant motor improvement, bilateral nail dyschromia (ND) with green nail discoloration was noticed (figure 1) within days after the change in therapeutic regimen. Two months after rotigotine withdrawal, ND completely disappeared (figure 2). Rotigotine is a nonergot dopamine agonist administered via transdermal patch technology. ${ }^{1}$ Drug-induced nail abnormalities, particularly ND, are well-known complications related to several drugs, including cancer chemotherapies, retinoids, tetracycline, and minocycline. ${ }^{2}$

Hélio A.G. Teive, MD, PhD, Renato P. Munhoz, MD, MSc, Curitiba, Paraná, Brazil

Author contributions: Hélio A. G. Teive: Drafting of the manuscript for content, including medical writing for content, study concept or design, analysis or interpretation of data. Renato P. Munhoz: Drafting/revision of the manuscript.

Disclosure: The authors report no disclosures.

Address correspondence and reprint requests to Dr. Hélio A.G. Teive, Rua General Carneiro 1103/102, Centro, Curitiba, Paraná, 80060-150,Brazil; hagteive@mps.com.br

1. Rascol O, Perez-Lloret S. Rotigotine transdermal delivery for the treatment of Parkinson's disease. Exp Opin Pharmacother 2009;10:677-691.

2. Piraccini BM, Iorizzo M, Antonucci A, Tosti A. Drug-induced nail abnormalities. Exp Opin Drug Saf 2004;3:57-65. 


\section{Neurology}

\section{Rotigotine-induced nail dyschromia in a patient with Parkinson disease Hélio A.G. Teive and Renato P. Munhoz Neurology 2011;76;1605 \\ DOI 10.1212/WNL.0b013e3182190f62}

\section{This information is current as of May 2, 2011}

\section{Updated Information \& Services}

References

Subspecialty Collections

Permissions \& Licensing

Reprints including high resolution figures, can be found at: http://n.neurology.org/content/76/18/1605.full

This article cites 2 articles, 0 of which you can access for free at: http://n.neurology.org/content/76/18/1605.full\#ref-list-1

This article, along with others on similar topics, appears in the following collection(s):

\section{All Clinical Neurology}

http://n.neurology.org/cgi/collection/all_clinical_neurology

Parkinson's disease/Parkinsonism

http://n.neurology.org/cgi/collection/parkinsons_disease_parkinsonism

Information about reproducing this article in parts (figures,tables) or in its entirety can be found online at:

http://www.neurology.org/about/about_the_journal\#permissions

Information about ordering reprints can be found online:

http://n.neurology.org/subscribers/advertise

Neurology ${ }^{\circledR}$ is the official journal of the American Academy of Neurology. Published continuously since 1951, it is now a weekly with 48 issues per year. Copyright Copyright @ 2011 by AAN Enterprises, Inc.. All rights reserved. Print ISSN: 0028-3878. Online ISSN: 1526-632X.

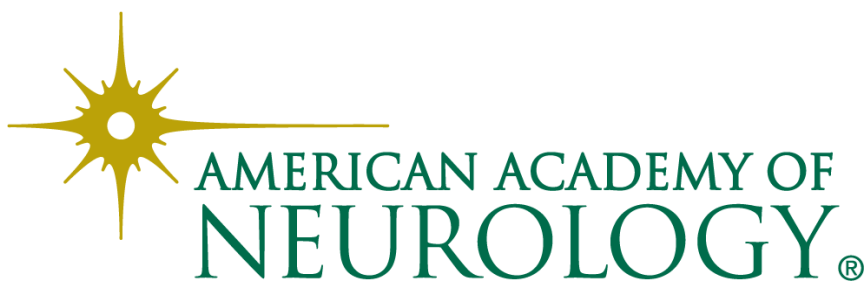

